\title{
ACYLATED (+)-CATECHIN GLYCOSIDES FROM ULMUS PUMILA L. GROWING IN EGYPT
}

\author{
Said Kotb Esmail \\ Department of Pharmacognosy, Faculty of Pharmacy (Boys), Al-Azhar University, Cairo, \\ Egypt.
}

\begin{abstract}
Extensive isolation work on the $n$-BuOH-soluble fraction obtained from the stem and root barks of Ulmus pumila L. afforded five compounds. Four were identified as (+)-catechin 1, $(+)$-catechin 7-O-gallate $2,(+)$-catechin-5-O- $\beta$-D-apiofuranoside 3, and (+)-catechin-7- $O-\beta$-Dapiofuranoside 4. The structures of the remaining new compound was elucidated to be, $(+)-$ catechin-7- $O$-gallate-5- $O$-(5“-trans-caffeoyl)- $\beta$-D-apiofuranoside-3- $O$ - $\beta$-D-apiofuranosyl$(1 \rightarrow 2)$-glucopyranoside $\mathbf{5}$, by chemical and spectroscopic analysis. The ethanolic and $n$-butanol extracts and the isolated compounds (1-5) were tested for their antioxidant activity using DPPH radical scavenging assay, xanthine oxidase-induced generation of superoxide radical and lipid peroxidation assay by thiobarbituric acid-reactive substances (TBARS) method using rat tissue homogenates.
\end{abstract}

Key words Ulmus pumila L. ; Ulmuaceae; acylated (+)-catechin glycosides, DPPH, Xanthine oxidase, Lipid peroxidation.

\section{INTRODUCTION}

Ulmus pumila L. (Ulmaceae) is a deciduous tree, which is widely distributed in Korea. The barks of the stem and root of this plant have been used in oriental traditional medicine for the treatment of oedema, mastitis, gastric cancer, and inflammation (Lee and Korean 1996; College, 1977). Protecting neurons from glutamate-induced neurotoxicity (Dong, et al., 2006). The effect of the $n-\mathrm{BuOH}$ fraction of the methanol extract of this plant in inhibition of inflammatory diseases may be partially associated with the inhibition of NO synthesis and iNOS induction in murine macrophages (Chiranjit et al., 2012). Phytochemical studies of this species have resulted in the isolation of various sesquiterpenes (Chen, et al., 1972; Kim, et al., 1996), tritrpenes, (Dong, et al., 2006; Kim, et al., 1992; Moon, et al., 1995) and flavonoids (Son, et al., 1989), but there have been no previous phytochemical reports on the $n$-BuOH fraction of this plant. In this paper, I describe chemical components of the $n$ - $\mathrm{BuOH}$ fraction of the methanol extract that led to the isolation and characterization of a series of (+)-catechin glycoside derivatives.

\section{RESULTS AND DISCUSSION}

\section{1- Phytochemical investigation}

The water-soluble portion of the methanolic extract of $U$. pumila $L$. was successively partitioned between hexane, chloroform and $n-\mathrm{BuOH}$ to give the corresponding soluble fractions. Chromatographic purification of the $n-\mathrm{BuOH}$ soluble fraction, furnished a new compound (5) and four known flavan-3-ol (1-4). The Spectra (UV, IR, ${ }^{1} \mathrm{H}$ and ${ }^{13} \mathrm{C} \mathrm{NMR}$, and FABMS) for isolated flavan-3-ols were in good agreement with thereported data for (+)- 
catechin $^{9)}(\mathbf{1}),(+)$-catechin-5-O- $\beta$-D-apiofuranoside (2) (Son, et al., 1989), (+)-catechin-7-O- $\beta-$ D-apiofuranoside (3) (Karl, et al., 1982), and (+)-catechin-7-O-gallate (4) (Malan and Pienear, 1982; Agrawal, 1989) and comparison with reference samples or reported data.

The new compound (5) contained the same flavan-3-ol of 4 [(+)-catechin-7-O-galloyl type] (Malan and Pienear, 1982; Agrawal, 1989) and was esterified with caffeoyl derivative attached to hydroxyl group on the sugar moiety.

Compound 5 gave a molecular ion (FAB-MS, positive ion mode) at $\mathrm{m} / \mathrm{z} 1031[\mathrm{M}+\mathrm{H}]^{+}$ , which together with the ${ }^{1} \mathrm{H}$ - and ${ }^{13} \mathrm{C}-\mathrm{NMR}$ spectral data was consistent with the empirical formula $\mathrm{C}_{47} \mathrm{H}_{50} \mathrm{O}_{26}$. Bands for hydroxyl and chelated carbonyl functional groups were suggested by IR, and the UV absorptions at $282 \mathrm{~nm}$ were typical for a flavan-3-ol (Mabry, et al., 1970). Acid hydrolysis of $\mathbf{5}$ furnished 1, caffeic acid, gallic acid and monosaccharide components, identified as glucose and apiose by co-TLC with authentic samples.

The downfield region of the ${ }^{1} \mathrm{H}-\mathrm{NMR}$ spectrum of $\mathbf{5}$ showed two spin systems correlated by ${ }^{1} \mathrm{H}-{ }^{1} \mathrm{H}-\mathrm{DQF}-\mathrm{COSY}$ : an AB system at $\delta 6.49(\mathrm{~d}, J=2.0 \mathrm{~Hz}, \mathrm{H}-6)$ and $\delta 6.68(\mathrm{~d}, J$ $=2.0 \mathrm{~Hz}, \mathrm{H}-8)$ and an ABX system of three aromatic protons for $\mathrm{H}-2$ ' $(\delta$ 7.15), $\mathrm{H}-5$ ' $(\delta$ 6.87), and $\mathrm{H}-6$ ' $(\delta 6.70)$ with meta $(J=1.8 \mathrm{~Hz})$, ortho $(J=8.6 \mathrm{~Hz})$ and ortho-meta $(\delta 8.6,1.8 \mathrm{~Hz})$. These two systems together with signals due to four aliphatic resonances as an ABMX-spin system of the heterocyclic C ring at $\delta 4.97(\mathrm{~d}, J=7.2 \mathrm{~Hz}, \mathrm{H}-2), \delta 4.32(\mathrm{dt}, J=7.2,5.5, \mathrm{H}-3), \delta$ 2.89 (dd, $J=16.8,5.5 \mathrm{~Hz}, \mathrm{H}-4_{\mathrm{eq}}$ ), and $\delta 2.66$ (dd, $J=16.8,9.2 \mathrm{~Hz}, \mathrm{H}-4^{\prime \prime}{ }_{\text {ax }}$ ) supported the presence of a typical flavan-ol of (+)-catechin type. ${ }^{9)}$ The large coupling constants between $\mathrm{H}-2$ and $\mathrm{H}-4$ protons and the ${ }^{13} \mathrm{C}-\mathrm{NMR}$ chemical shifts for $\mathrm{C}-2(\delta 83.38), \mathrm{C}-3(\delta 73.75)$ and $\mathrm{C}-4$ (27.26) respectively, reflecting a 2,3-trans and a 3,4-trans stereochemistry (Balas, et al., 1995).

The other groups of signals in the downfield region of the ${ }^{1} \mathrm{H}-\mathrm{NMR}$ spectrum indicated the presence of two ester functionalites. Two olefinic protons observed as an AX system at $\delta$ 7.65 and $6.52\left(\mathrm{~d}, J_{\mathrm{AX}}=15.8 \mathrm{~Hz}\right)$ and three aromatic protons as an AMX system at $\delta 7.18(\mathrm{~d}, J$

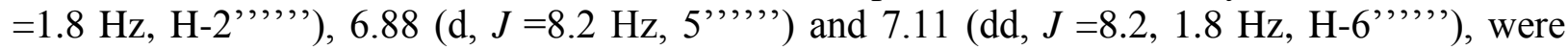
consistent with the presence of an trans-caffeoyl moiety confirmed with the presence of nine signals in the ${ }^{13} \mathrm{C}-\mathrm{NMR}$ spectrum (Hosny and Rosazza, 1998). The second acyl moiety was established as a galloyl moiety (Lee, $\boldsymbol{e t ~ a l . , ~ 2 0 0 0 ) , ~ w h i c h ~ o b s e r v e d ~ a s ~ t w o ~ e q u i v a l e n t ~ p r o t o n s , ~} \mathrm{H}$ $2 ", "$, and H-6"," and appearing as a sharp singlet integrated to two protons at $\delta$ 7.33. Downfield shifts in ${ }^{13} \mathrm{C}-\mathrm{NMR}$ for C-3 ( $\delta$ 73.75), C-5 ( $\delta$ 159.45) and C-7 ( $\left.\delta 158.11\right)$ versus $(+)-$ catechin 1, confirmed functionalizations at these positions. The galloyl residue was located at the 7-O-position of 5 by HMBC, in which the carbonyl carbon at $\delta 166.90$ showed long-range correlations with the two meta-related 6- and 8- protons of the A-ring (Figure 1). 


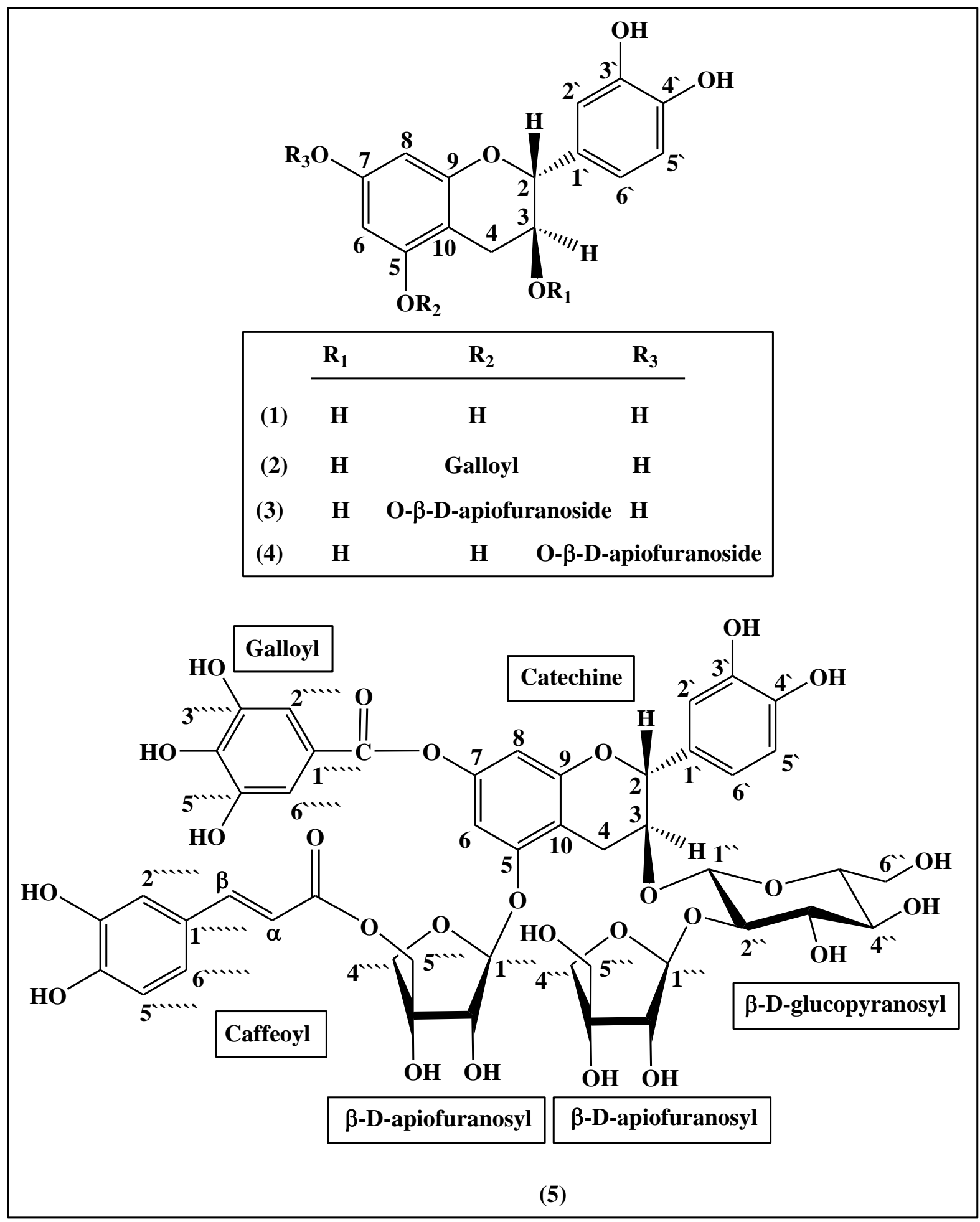

(Figure 1) Structures of isolated compounds (1-5) from Ulmus pumila L. 
(Table 1) ${ }^{1} \mathrm{H}$ - and ${ }^{13} \mathrm{C}-\mathrm{NMR}$ Data for Compound (5) ${ }^{\mathrm{a}}$ (DMSO- $\left.d_{6}, 600 \mathrm{MHz}\right)$

\begin{tabular}{|c|c|c|c|c|c|}
\hline No & $\delta^{1} H$ & $\delta^{13} \mathrm{C}$ & \multirow{2}{*}{$\begin{array}{l}\text { No } \\
3^{\prime \prime \prime}\end{array}$} & $\delta^{1} H$ & $\delta^{13} \mathrm{C}$ \\
\hline \multicolumn{3}{|c|}{ (+)-Catechine moiety } & & & $81.38 \mathrm{~s}$ \\
\hline 2 & $\begin{array}{lll}4.97 \mathrm{~d} & (7.2)\end{array}$ & 83.38 & $\begin{array}{l}4 \text { "'A } \\
4 \text { "'B }\end{array}$ & $\begin{array}{lll}4.08 \mathrm{~d} & (10.2) \\
3.76 & \mathrm{~d} & (10.2)\end{array}$ & $75.94 \mathrm{t}$ \\
\hline 3 & $4.32 \mathrm{dt} \quad(7.2,5.5)$ & 73.75 & $\begin{array}{l}\text { 5"'A } \\
\text { 5"'B }\end{array}$ & $\begin{array}{lll}3.62 & \mathrm{~d} & (10.2) \\
3.67 & \mathrm{~d} & (10.2)\end{array}$ & $65.36 \mathrm{t}$ \\
\hline $\begin{array}{l}\mathbf{4}_{\mathrm{eq}} \\
\mathbf{4}_{\mathrm{ax}}\end{array}$ & 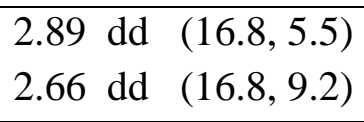 & 27.26 & \multicolumn{3}{|c|}{$\begin{array}{l}\text { Sugar moiety at (C-5) } \\
\beta \text {-D-apiofuranosyl moiety }\end{array}$} \\
\hline 5 & - & 159.45 & $1 "$ "'" & \begin{tabular}{l|l} 
& $5.32 \mathrm{~d}(2.6)$
\end{tabular} & $111.32 \mathrm{~d}$ \\
\hline 6 & $6.49 \mathrm{~d} \quad(2.0)$ & 98.10 & $2 " ' "$ & $4.01 \mathrm{~d}(2.6)$ & $78.65 \mathrm{~d}$ \\
\hline 7 & - & 158.11 & 3 3"'" & & $81.38 \mathrm{~s}$ \\
\hline 8 & $6.68 \mathrm{~d} \quad(2.0)$ & 94.72 & $\begin{array}{l}4 \text { 4"'A } \\
4 \text { "'"B }\end{array}$ & $\begin{array}{lll}3.83 & \mathrm{~d} & (10.1) \\
4.12 & \mathrm{~d} & (10.1)\end{array}$ & $75.94 \mathrm{t}$ \\
\hline 9 & - & 156.22 & $\begin{array}{l}\text { 5'"'A } \\
5 \text { '"'B }\end{array}$ & $\begin{array}{l}4.62 \mathrm{~d}(10.5) \\
4.67 \mathrm{~d}(10.5)\end{array}$ & $65.36 \mathrm{t}$ \\
\hline 10 & - & 104.85 & \multicolumn{3}{|c|}{ Ester moiety } \\
\hline 1 & - & 131.25 & $1 " \cdots " '$ & - & $120.60 \mathrm{~s}$ \\
\hline $\mathbf{2}^{\prime}$ & $7.15 \mathrm{~d}$ & 114.76 & $2 " ' " ', 6$ "'"' & $7.33 \mathrm{~s}$ & $109.79 \mathrm{~d}$ \\
\hline 3 & - & 149.50 & 3"'"', 5'"'" & - & $147.30 \mathrm{~s}$ \\
\hline 4 & - & 147.80 & 4 4"'"' & - & $141.10 \mathrm{~s}$ \\
\hline 5' & $6.87 \mathrm{~d} \quad(8.6)$ & 116.10 & $\mathrm{C}=\mathrm{O}$ & - & $166.90 \mathrm{~s}$ \\
\hline 6' & $6.70 \mathrm{dd}(8.6,1.8)$ & 120.58 & \multicolumn{3}{|c|}{ Caffeoyl } \\
\hline \multicolumn{3}{|c|}{$\begin{array}{l}\text { Sugar moiety at C-3 } \\
\beta \text {-D-glucopyranosyl moiety }\end{array}$} & $1 " \cdots+" 1$ & - & $126.13 \mathrm{~s}$ \\
\hline 1" & $\begin{array}{ll}5.06 \mathrm{~d} & (7.7)\end{array}$ & $100.80 \mathrm{~d}$ & $2 " ' \cdots " '$ & $7.18 \mathrm{~d}(1.8)$ & $114.65 \mathrm{~d}$ \\
\hline 2" & $4.53 \mathrm{dd}(9.7,7.7)$ & $79.13 \mathrm{~d}$ & 3"'"'"' & - & $146.82 \mathrm{~s}$ \\
\hline 3" & $3.51 \mathrm{t} \quad(9.7)$ & $75.49 \mathrm{~d}$ & 4"'"'" & - & $148.15 \mathrm{~s}$ \\
\hline 4" & $3.39 \mathrm{t} \quad(9.7)$ & $70.18 \mathrm{~d}$ & 5 5'"'" & $6.88 \mathrm{~d} \quad(8.2)$ & $116.22 \mathrm{~d}$ \\
\hline 5" & $3.44 \mathrm{~m}$ & $78.13 \mathrm{~d}$ & 6"'"'" & $7.11 \mathrm{dd}(8.2,1.8)$ & $123.18 \mathrm{~d}$ \\
\hline $\begin{array}{l}6^{\prime \prime} \\
\text { A } \\
6 " \\
\text { B }\end{array}$ & $\begin{array}{l}3.90 \mathrm{dd}(12.2,2.2) \\
3.72 \mathrm{dd}(12.2,5.6)\end{array}$ & $61.49 \mathrm{t}$ & $\alpha$ & $6.52 \mathrm{~d} \quad(15.8)$ & $114.12 \mathrm{~d}$ \\
\hline$\beta-\mathrm{D}$ & apiofuranosyl moiet & & $\beta$ & 7.65 d (15.8) & $147.64 \mathrm{~d}$ \\
\hline 1 1"' & $5.21 \mathrm{~d} \quad(2.3$ & $111.32 \mathrm{~d}$ & $\mathrm{C}=\mathrm{O}$ & - & $167.26 \mathrm{~s}$ \\
\hline $2 " '$ & $3.87 \mathrm{~d} \quad(2.3)$ & $78.65 \mathrm{~d}$ & & & \\
\hline
\end{tabular}

${ }^{\text {a }}$ Assignments were confirmed by COSY, ROESY, HMQC and HMBC spectra at $600 \mathrm{MHz}$. 
The sugars of 5 were evidenced by three anomeric proton and carbon signals in ${ }^{1} \mathrm{H}$ - and ${ }^{13} \mathrm{C}-\mathrm{NMR}$ spectra (Table 1 and 2 ) with anomeric proton signals at $\delta 5.06(\mathrm{~d}, J=7.7 \mathrm{~Hz}, \mathrm{H}-1$ ' '), $5.21\left(\mathrm{~d}, J=2.3 \mathrm{~Hz}, \mathrm{H}-1^{\prime \prime}\right.$, ) and 5.32 (d, $\left.J=2.6 \mathrm{~Hz} \mathrm{H}-1^{,,},{ }^{\prime}\right)$ which correlated respectively with signals at $\delta 100.80,111.32$ and 110.70 respectively, in the HMQC spectrum. Additionally, DQF-COSY allowed the sequential assignments of all proton resonances within each sugar residue, starting from the well-isolated anomeric proton signals. Thus, on the basis of the chemical shifts, multiplicity of the signals, and absolute values of the coupling constants, the three sugar residues were identified as a $\beta$-D-glucopyranosyl ${ }^{(15)}$ and two $\beta$-D-apiofuranosyl ${ }^{(17}$, 18). The two apiofuranosyl groups were also identified by their $\mathrm{C}-3$ being quaternary carbons $(\delta$ 81.38, C-1',' and 80.60, C-1',','), and C-4 ( $\delta$ 75.94, t, C-4',', 75.82, t, C-4 ',', $)$ and C-5 ( $\delta 65.36$ t, C-5 ', , $68.55 \mathrm{t}, \mathrm{C}-5$ ',') being two methylene carbons and by comparing the ${ }^{13} \mathrm{C}-\mathrm{NMR}$ spectra data of 5 with those of $\alpha-\mathrm{D}-(\delta$ 104.20) and $\beta$-D-apiofuranosides $(\delta$ 111.50), respectively (Kitagawa, et al., 1993).

${ }^{13} \mathrm{C}-\mathrm{NMR}$ spectrum of $\mathbf{5}$ showed 47 carbon signals, of which 22 were similar to those of (+)-catechin-7-O-gallate $\mathbf{4}^{(11,12)}$ and the remaining according to DEPT NMR analysis indicated 5 $\mathrm{sp}^{3}$ methylenes, $5 \mathrm{sp}^{2}$ methines, $9 \mathrm{sp}^{3}$ methines, $4 \mathrm{sp}^{2}$ quaternary carbons and $2 \mathrm{sp}^{3}$ quaternary carbons atoms attributed to one glucosyl, two apiosyl and one caffeoyl moieties. Glycosidic substitutions for C-3 and C-5 were suggested by downfield shifts in the ${ }^{13} \mathrm{C}-\mathrm{NMR}$ spectrum for C-3 $(\delta 73.75)$ and C-5 ( $\delta$ 159.45) relative to the corresponding signals of $\mathbf{1}$. The disaccharide chain contained one $\beta$-glucose and one $\beta$-apiose units at $\mathrm{C}-3$, and the interglycosidic linkage was established at $\mathrm{C}-2$ of the glucose unit on the basis of the pronounced downfield shifts exhibited by this carbon resonance $(\delta 79.13)$ and of $\mathrm{H}-2$ of the glucose $(\delta 4.53, \mathrm{~d}, J=9.7,7.7$ $\mathrm{Hz}$ ) when compared to the respective shift in unglycosylated models (Hosny and Rosazza, 1998). Analysis of cross correlations by HMBC and ROESY established the interglycosidic connectivities, showing long-range correlations between H-1 ( $\delta 5.06)$ of the $\beta$-D-glucose unit and $\mathrm{C}-3$ of the aglycon $(\delta 73.75), \mathrm{H}-1$ of $\beta$-D-apiose unit $(\delta 5.32)$ and $\mathrm{C}-5$ ( $\delta$ 159.45) of aglycon; C-2 ( $\delta$ 79.13) of $\beta$-D-glucose unit and H-1 $(\delta 5.21)$ of the $\beta$-D-apiose unit. The observed ROESY interaction between $\mathrm{H}-1$ of $\beta$-D-glucose and $\mathrm{H}-2, \mathrm{H}-3$ and $\mathrm{H}_{2}-4$ of the aglycon; and between $\mathrm{H}-1$ and $\mathrm{H}-2$ of the glucose unit and $\mathrm{H}-1$ of $\beta$-D-apiose unit and the absence of any glycoylation shifts for their carbon resonances indicated the attachment of the terminal sugar moiety to the aglycon.

Additionally, the significant deshielding of $\mathrm{H}_{2}-5$,', of apiose ( $\delta 4.62$ and 4.67 each $\mathrm{d}, J$ $=10.5 \mathrm{~Hz}$ ) and the HMBC cross-peaks between these proton signals and the carbonyl carbon at $\delta 167.26$ confirmed that the caffeoyl unit was attached to position 5 of $\beta$-D-apiose. Thus, 5 was established as (+)-catechin-7- $O$-gallate-5-O-(5',', -trans-caffeoyl)- $\beta$-D-apiofuranoside-3-O- $\beta$ D-apiofuranosyl- $(1 \rightarrow 2)$-glucopyranoside.

\section{2- In-vitro biological evaluation}

\section{a- DPPH radical scavenging activity (Hosny, et al., 2002).}

All the tested samples had significant scavenging effects on the DPPH radical. The results recorded in (Table 2 ) indicated that compound $\mathbf{5}$ showed the highest activity among all the tested samples $(84.8 \%)$, followed by the $n$-butanol fraction $(70.3 \%)$ and the ethanolic extract $(67.2 \%)$, and they were higher than $\alpha$-tocopherol and BHT (66.5 and 55.3\%, respectively). The results obtained for the n-butanol fractions and compound $\mathbf{5}$ indicated that the flavonoidal 
content, ester moieties and sugar units are responsible for the scavenging effects, and this could be attributed to their hydrogen donating activity. In general, the phenolic $\mathrm{OH}$ is considered a scavenger of free radicals, and it consequently exhibits antioxidative activity (Hosny, et al., 2002).

\section{b- Xanthine oxidase-induced generation of superoxide radical (Gongora, et al., 2003).}

The tested samples inhibited superoxide-induced reduction of nitro-blue tetrazolium, which depends on direct inhibition of xanthine oxidase enzyme as shown in (Table 2). The major isolated flavonoid compounds: 5 and $\mathbf{2}$ showed the highest activity with $\mathrm{IC}_{50}=34.2 \mu \mathrm{M}$ and $39.2 \mu \mathrm{M}$; respectively, followed by compounds $1\left(\mathrm{IC}_{50}=41.5 \mu \mathrm{M}\right), 4\left(\mathrm{IC}_{50}=42.5 \mu \mathrm{M}\right)$, and $3\left(\mathrm{IC}_{50}=45.8 \mu \mathrm{M}\right)$, and they were higher than $\alpha$-tocopherol and $\mathrm{BHT}\left(\mathrm{IC}_{50}=78.5 \mu \mathrm{M}\right.$ and $\mathrm{IC}_{50}$ $=130.7 \mu \mathrm{M}$ respectively) and less than Allopurinol $\left(\mathrm{IC}_{50}=18.0 \mu \mathrm{M}\right)$. The $n$-butanol fraction showed highest activity with $\left(\mathrm{IC}_{50}=47.5 \mu \mathrm{M}\right)$ than the ethanolic fraction $\left(\mathrm{IC}_{50}=76.8 \mu \mathrm{M}\right)$.

Phenolic compounds are known to inhibit generation of the superoxide anion radical $\left(\mathrm{O}^{2 \cdot-}\right)$ in the hypoxanthine-xanthine oxidase system. The radical scavenging action of these phenolic compounds is through the formation of stable free radicals, which contribute to the inhibitory effects on lipid peroxidation and participate in the inhibition of $\left(\mathrm{O}^{2 \cdot-}\right)$ generation. Since the $n$-butanol fractions is rich in $(+)$-catechin derivatives which were reported to have activities regarding inhibition of xanthine oxidase enzyme (Gongora, et al., 2003). Therefore, these fractions could be effective as natural antioxidants, through their double ability to inhibit xanthine oxidase activity and superoxide anion production, and could be considered an effective strategy in the treatment of inflammation.

Table 2. Effects of the tested samples on the in vitro free radical generation

\begin{tabular}{|l|c|c|}
\hline Bioassay sample & DPPH \% inhibition & $\begin{array}{l}\text { Xanthine oxidase } \\
\text { IC50 }(\boldsymbol{\mu M})\end{array}$ \\
\hline Ethanolic extract & $58.5 \pm 1.50$ & $76.8 \pm 2.90$ \\
\hline$n$-butanol fraction & $70.3 \pm 2.20$ & $47.5 \pm 2.10$ \\
\hline Compound (1) & $65.9 \pm 1.95$ & $41.5 \pm 1.85$ \\
\hline Compound (2) & $67.2 \pm 2.10$ & $39.2 \pm 1.80$ \\
\hline Compound (3) & $59.6 \pm 1.70$ & $45.8 \pm 2.10$ \\
\hline Compound (4) & $61.5 \pm 1.80$ & $42.5 \pm 2.10$ \\
\hline Compound (5) & $84.5 \pm 2.44$ & $34.2 \pm 1.75$ \\
\hline DL- $\alpha$-tocopherol & $66.5 \pm 2.75$ & $78.5+2.88$ \\
\hline BHT & $55.10 \pm 1.50$ & $130.7+4.35$ \\
\hline Allopurinol & - & $18.0 \pm 0.25$ \\
\hline
\end{tabular}

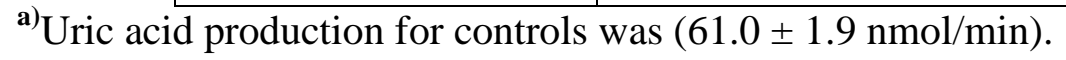

All tested samples and positive controls were tested at $100 \mu \mathrm{g} / \mathrm{mL}$.

Values are presented as mean $\pm \mathrm{SE}$ of 3-test sample observation. $\mathrm{P}<0.05$ for all values. 


\section{c- $\mathrm{FeSO}_{4} / \mathrm{H}_{2} \mathrm{O}_{2}$-stimulated lipid peroxidation in rat tissue homogenate (Hino, et al., 1998; Hosny and Rosazza, 2002).}

For rat tissue homogenate (brain, heart and liver), the unstimulated control experiments i.e. the amount of thiobarbituric reactive substance (TBARS) formed in rat tissue homogenate (brain, heart and liver) were $(0.44 \pm 0.05,0.25 \pm 0.03$ and $0.19 \pm 0.02 \mathrm{nmol}$ malondialdehyde, MDA/mg protein, respectively). After induction with $\mathrm{FeSO}_{4} / \mathrm{H}_{2} \mathrm{O}_{2}$, the amount of TBARS increased to $0.90 \pm 2.55,0.60 \pm 2.16$ and $0.52 \pm 1.25 \mathrm{nmol}$ malondialdehyde, $\mathrm{MDA} / \mathrm{mg}$ protein, for brain, heart and liver, respectively. The tested samples significantly reduced malondialdehyde (MDA) formation in the presence of $\mathrm{FeSO}_{4}-\mathrm{H}_{2} \mathrm{O}_{2}$ in tissue homogenates indicating anti-lipid peroxidation activities. The inhibition percentages were in the range of (55.10-80.78\%), (48.75-71.50\%) and (32.75-78.25\%) in liver, heart and brain, rat tissue homogenates, respectively as recorded in (Table 3).

Table 3. Inhibition effects of the tested samples on $\mathrm{FeSO}_{4} / \mathrm{H}_{2} \mathrm{O}_{2}$-stimulated lipid peroxidation (MDA production) in rat tissue homogenates in vitro

\begin{tabular}{|c|c|c|c|}
\hline \multicolumn{4}{|c|}{ Inhibition (\%) } \\
\hline $\begin{array}{c}\text { Bioassay Sample } \\
200 \mu \mathrm{g} / \mathrm{mL}\end{array}$ & Liver & Heart & Brain \\
\hline Ethanolic extract & $64.82 \pm 2.05$ & $60.05 \pm 1.85$ & $53.10 \pm 1.80$ \\
\hline$n$-butanol fraction & $75.60 \pm 1.97$ & $50.22 \pm 1.80$ & $70.90 \pm 2.15$ \\
\hline Compound (1) & $66.18 \pm 2.10$ & $54.10 \pm 1.80$ & $49.75 \pm 1.76$ \\
\hline Compound (2) & $75.60 \pm 1.97$ & $50.22 \pm 1.80$ & $70.90 \pm 2.15$ \\
\hline Compound (3) & $55.10 \pm 2.28$ & $52.40 \pm 2.18$ & $43.90 \pm 2.25$ \\
\hline Compound (4) & $43.50 \pm 1.55$ & $48.75 \pm 1.28$ & $32.75 \pm 1.80$ \\
\hline Compound (5) & $80.78 \pm 3.12$ & $71.50 \pm 2.35$ & $78.25 \pm 3.10$ \\
\hline DL- $\alpha$-tocopherol & $62.90 \pm 2.18$ & $58.70 \pm 1.80$ & $71.10 \pm 2.25$ \\
\hline BHT & $52.48 \pm 1.72$ & $43.23 \pm 1.65$ & $53.20 \pm 1.65$ \\
\hline
\end{tabular}

a) Values are presented as mean \pm SE of 3-test sample observations, $\mathrm{P}<0.05$ for all values;

It was interesting to note that the inhibition effects produced by the tested samples were more pronounced for liver tissue homogenates than heart and brain tissue homogenates, which could be especially beneficial in treatment of liver disease in cases with oxidative stress due to elevated levels of TBARS (Hino, et al., 1998; Hosny and Rosazza, 2002). The n-butanol extract and compound $\mathbf{5}$ showed the highest inhibition activity against $\mathrm{FeSO}_{4} / \mathrm{H}_{2} \mathrm{O}_{2}$-stimulated lipid peroxidation in liver rat tissue homogenate (75.60 and $80.78 \%$ ), respectively, which was higher than both reference standards. Since DL- $\alpha$-tocopherol is thought to be associated with lipid-rich membranes; its anti-oxidative ability is highly effective in protecting membranes against lipid peroxidation, as peroxyl and alkoxyl radicals. The data obtained from the present study indicates that the tested extracts have an anti-lipid peroxidative character with similar reaction mechanisms to those of DL- $\alpha$-tocopherol.

\section{CONCLUSIONS}

This study provides strong evidence for the antioxidant activities of the n-butanol fraction obtained from the stem and root barks of Ulmus pumila L. Planch (Ulmaceae). The 
results obtained for the n-butanol fraction and the isolated catechin derivatives (1-5), indicated that the flavonoid compounds in studied plant are responsible for the scavenging effects through several mechanisms like hydrogen donating activity, inhibition of xanthine oxidase activity and superoxide anion production, as well as protection of membranes against lipid peroxidation. This could be potentially useful for the treatment of major free radicalinduced degenerative diseases including brain dysfunction, inflammation, and liver disorders. Further in-vivo studies could be done to support this point of view.

\section{Experimental}

General Procedures Optical rotations were measured with a JASCO P-1020 digital polarimeter. UV spectra were recorded using a Hitachi 340 spectrophotometer. IR absorbtion spectra $\left(\mathrm{cm}^{-1}\right)$ were obtained with a Nicolet 205 FT-IR spectrometer connected to a HewlettPackard ColorPro plotter. HR-FAB-MS were recorded on a VG-ZAB-HF reversed geometry (BE configuration, where $\mathrm{B}$ is a magnetic sector and $\mathrm{E}$ is an electrostatic analyzer) mass spectrometer (MS) (VG Analytical, Inc.). ${ }^{1} \mathrm{H}$ - and ${ }^{13} \mathrm{C}-\mathrm{NMR}$ spectra were obtained with a Bruker NMR 400 (Bruker Instruments, Billerica, MA), operating at $400 \mathrm{MHz}$ for ${ }^{1} \mathrm{H}$, and 100 $\mathrm{MHz}{ }^{13} \mathrm{C}$, respectively, in DMSO- $d_{6}$ using TMS as the internal standard. Chemical shifts are reported in parts per million on the $\delta$ scale and coupling constants are in Hertz. Routine ${ }^{1} \mathrm{H}$ - and ${ }^{13}$ C-NMR spectra DQF-COSY, ROESY, HMQC and HMBC-NMR experiments were carried out using a Bruker AMX-600 high-field spectrometer equipped with an IBM Aspect-2000 processor and with software VNMR version 4.1. Column chromatographies were performed with a high porosity polystyrene gel Diaion HP-20 (Mitsubishi Kasei Co., Ltd., Tokyo, Japan), flash silica gel $(40 \mu \mathrm{m})$ and Sepralyte $\mathrm{C}_{18}(40 \mu \mathrm{m})(\mathrm{J}$. T. Baker, Phillipsburg, NJ, USA), Sephadex LH-20 (25-150 $\mu$ m, Pharmacia Fine Chemical Co Ltd.). TLC was carried out on precoated silica gel $60 \mathrm{~F}_{254}$ plates $\left(0.2 \mathrm{~mm}\right.$ thick, Merck) with solvent systems: $\mathrm{A} \mathrm{CHCl}_{3-}$ MeOH- $\mathrm{H}_{2} \mathrm{O}$ (80: 20: 2, v/v/v), B EtOAc-MeOH- $\mathrm{H}_{2} \mathrm{O}$ (100: 16.5: 13.5, v/v/v), C CHCl $3-\mathrm{MeOH}-$ $\mathrm{H}_{2} \mathrm{O}(61: 32: 7 \mathrm{v} / \mathrm{v} / \mathrm{v})$. Developed chromatograms were visualized by fluorescence quenching under 245 -nm UV light and by spraying with $1 \%$ vanillin $/ \mathrm{H}_{2} \mathrm{SO}_{4}$, followed by heating at $100^{\circ} \mathrm{C}$ for $5 \mathrm{~min}$.

Plant Material The stem and root barks of $U$. pumila L. var. Japonica were collected from Al-Orman garden, Giza in May 2010, and identified by Dr. Mohammed El-Gibally, plant Taxonomist, Consultant of Egyptian Flora, Al-Orman garden, Giza, Egypt.

Extraction and Isolation The dried stem and root barks of $U$. pumila $L . \quad(1.2 \mathrm{Kg})$ were cut into coarse powder and dried in shade exhaustively extracted at room temperature with $\mathrm{MeOH}(3 \mathrm{X} 5 \mathrm{~L})$. The combined $\mathrm{MeOH}$ extracts were concentrated in vacuo at $30^{\circ} \mathrm{C}$ to a brown residue $(195 \mathrm{~g})$. The concentrated extract was suspended in $\mathrm{H}_{2} \mathrm{O}(200 \mathrm{~mL})$ and filtered through Celite 545 (Fisher Scientific, Fair Lawn, NJ, USA). The filtrate and $\mathrm{H}_{2} \mathrm{O}$ washings $(350 \mathrm{~mL}$ ) were combined and washed with $n$-hexane $(3 \times 700 \mathrm{~mL})$. The aqueous fraction $(275 \mathrm{~mL})$ was concentrated in vacuo to give a crude extract of $(95 \mathrm{~g})$ that was partitioned first with $\mathrm{CHCl}_{3}$ (3 $\mathrm{X} 2 \mathrm{~L})$ and then with $n-\mathrm{BuOH}(3 \mathrm{X} 2 \mathrm{~L})$. The $n-\mathrm{BuOH}$ extract was concentrated in vacuo at $30^{\circ} \mathrm{C}$ and the residue ( $34 \mathrm{~g}$ ) was dissolved in $\mathrm{H}_{2} \mathrm{O}(10 \mathrm{~mL})$ and chromatographed over a Diaion HP-20 column $\left(3.5 \times 90 \mathrm{~cm}\right.$ ) eluted with $\mathrm{H}_{2} \mathrm{O}$ initially, with increasing concentrations of $\mathrm{MeOH}$ while being monitored by TLC (solvent systems $\mathrm{B}$ and $\mathrm{C}$ ). Fractions were grouped as $\mathrm{A},\left(\mathrm{H}_{2} \mathrm{O}, 8.395\right.$ $\mathrm{g}), \mathrm{B}\left(25 \% \mathrm{MeOH} / \mathrm{H}_{2} \mathrm{O}, 5.780 \mathrm{~g}\right), \mathrm{C}\left(50 \% \mathrm{MeOH} / \mathrm{H}_{2} \mathrm{O}, 4.675 \mathrm{~g}\right), \mathrm{D}\left(75 \% \mathrm{MeOH} / \mathrm{H}_{2} \mathrm{O}, 1.648 \mathrm{~g}\right)$. Fraction B $(5.780 \mathrm{~g})$ was rechromatographed over polyamide (SC6, Machery-Nagel, Düren, 
Germany $3.5 \times 90 \mathrm{~cm}$ ), and fractions eluting with 15, 20 and $30 \%$ aqueous $\mathrm{MeOH}$ were combined separately for further silica gel, flash column chromatography using $\left(\mathrm{CH}_{2} \mathrm{Cl}_{2}-\mathrm{MeOH}-\right.$ $\mathrm{H}_{2} \mathrm{O}$, 90:10:1 $\rightarrow$ 70:30:3) and repeated reversed-phase, Sepralyte $\mathrm{C}_{18}$ flash column chromatography, using a $\mathrm{H}_{2} \mathrm{O}-\mathrm{MeOH}$ gradient solvent system $(10 \rightarrow 40 \%, 3 \mathrm{~mL} \mathrm{~min})$ and further purified by Sephadex LH-20 eluted with $\mathrm{CHCl}_{3}-\mathrm{MeOH}, 7: 3$ ) to afford compounds 1 (786 $\mathrm{mg}), 2$ (88 mg), 3 (23 mg) and 4 (36 mg). Fractions B was chromatographed again over silica gel flash column $(2.5 \times 62 \mathrm{~cm})$ using (EtOAc- $\mathrm{MeOH}, 90: 10 \rightarrow 60: 40)$ to yield five subfractions, B1, B2 and B3. Subfractions B1 (745 mg), (560 mg) was subjected separately to Sepralyte $\mathrm{C}_{18}$ flash column chromatography $(1.5 \times 50 \mathrm{~cm})$, using a $\mathrm{H}_{2} \mathrm{O}-\mathrm{MeOH}$ gradient solvent system $(10 \rightarrow 30 \%)$ at a flow rate of $3 \mathrm{~mL}$ min. Final sample purification was carried out with Sephadex LH-20 eluted with $\left(\mathrm{CHCl}_{3}-\mathrm{MeOH}\right.$ 1:1) to afford compound 5 (35 mg).

Compounds 1-4 gave UV, IR, ${ }^{1} \mathrm{H}$ and ${ }^{13} \mathrm{C}-\mathrm{NMR}$, and FABMS data for $[\mathrm{M}+\mathrm{H}]^{+}$

ions in good agreement with reported data for (+)-catechin $(\mathbf{1})\left(\mathrm{C}_{15} \mathrm{H}_{15} \mathrm{O}_{6}[\mathrm{M}+\mathrm{H}]^{+}\right.$, 291) (Son, et al., 1989); (+)-catechin-5-O- $\beta$-D-apiofuranoside (2) $\left(\mathrm{C}_{20} \mathrm{H}_{23} \mathrm{O}_{10},[\mathrm{M}+\mathrm{H}]^{+}, 423\right)$; (Son, et al., 1989); (+)-catechin-7-O- $\beta$-D-apiofuranoside (3) $\mathrm{C}_{20} \mathrm{H}_{23} \mathrm{O}_{10},[\mathrm{M}+\mathrm{H}]^{+}$, 423) (Karl, et al., 1982); and (+)-catechin-7-O-gallate (4) $\left(\mathrm{C}_{22} \mathrm{H}_{19} \mathrm{O}_{10}[\mathrm{M}+\mathrm{H}]^{+}\right.$, 443) (Malan and Pienear, 1987);

Compound 5: obtained as amorphous powder $(35 \mathrm{mg}) ;[\alpha]^{25}{ }_{\mathrm{D}}-73.40^{\circ}(c 0.82, \mathrm{MeOH})$; IR $(\mathrm{KBr}) v_{\max } 3385,2918,1618,1600,1520,1270,1083,825 \mathrm{~cm}^{-1}$; UV (MeOH): $\lambda_{\max } 218$ (4.24), 282 (3.77) nm; ${ }^{1} \mathrm{H}$ - and ${ }^{13} \mathrm{C}$ - NMR (Tables 1 and 2); HR-FAB-MS m/z 1031.2665 [M + $\mathrm{H}]^{+}$(calcd for $\mathrm{C}_{47} \mathrm{H}_{51} \mathrm{O}_{26}, 1031.2668$ ).

\section{In-vitro biological Evaluation}

\section{Chemicals}

1,1-Diphenyl-2-picrylhydrazyl (DPPH), butylated hydroxytoluene (BHT), 2thiobarbituric acid, ferrous sulphate, hydrogen peroxide, xanthine oxidase from bovine milk, allopurinol, were from (Sigma, St. Louis, Mo, USA);

\section{Animals}

Male Wistar rats (250-300 g) were handled according to international regulations. They were allowed to take standard laboratory diet and water ad libitum, and the animals were maintained at $24^{\circ} \mathrm{C}$ with $12 \mathrm{~h}$ light period.

\section{DPPH radical scavenging activity}

The ability of the extracts to scavenge free radicals was determined according to the method of Hosny, et al 2002 ${ }^{(\mathbf{1 9})}$. In a 96-well plate, $10 \mu \mathrm{L}$ of each sample or standard dissolved in ethanol $(100 \mu \mathrm{g} / \mathrm{mL})$ was added to $190 \mu \mathrm{L}$ of $316 \mu \mathrm{M} / \mathrm{mL}$ DPPH solution. A blank was prepared using ethanol. After incubation at $30{ }^{\circ} \mathrm{C}$ for $30 \mathrm{~min}$, the absorbance of each solution was measured at $517 \mathrm{~nm}$. DL- $\alpha$-tocopherol and BHT were used as positive controls. The scavenging activity of the samples was calculated as a percentage of free radical inhibition according to the formula:

$$
\% \text { inhibition }=\underline{{ }^{\mathbf{A}} \text { blank }-{ }^{\mathbf{A}} \text { Sample }}
$$

${ }^{\mathrm{A}}$ blank

$\times 100$

where A blank is the absorbance of the blank at zero time and Asample is the absorbance of the sample after $30 \mathrm{~min}$. All experiments were carried out in triplicate. 


\section{Xanthine oxidase-induced generation of superoxide radical}

The effect of the tested samples was measured according to the method described by Gongora et al., (2003) with slight modification. Superoxide was generated by oxidation of hypoxanthine $(100 \mu \mathrm{M})$ with bovine milk xanthine oxidase in $1 \mathrm{~mL}$ of $10 \mathrm{mM} \mathrm{KH} 2 \mathrm{PO} 4-\mathrm{KOH}$ buffer, $\mathrm{pH} 7.4$, and was detected by the reduction of nitroblue tetrazolium (NBT) at $100 \mu \mathrm{M}$, followed spectrophotometrically at $560 \mathrm{~nm}$. DL- $\alpha$-tocopherol and BHT were used as positive controls. The effects of the test samples on enzyme activity was studied by measuring the uric acid formation from xanthine $(2-25 \mu \mathrm{M})$ after 15 min incubation at $25^{\circ} \mathrm{C}$, while absorbance was measured at $295 \mathrm{~nm}$ using allopurinol as a reference standard. The inhibitory activity of the tested samples and isolated compound in terms of $\mathrm{IC}_{50}$, i.e. the concentration required for $50 \%$ inhibition of uric acid formation was calculated by linear regression analysis.

FeSO4/H2O2-stimulated lipid peroxidation in rat tissue homogenate (Hino, et al., 1998; Hosny and Rosazza, 2002).

Male Wistar rats (250-300 g) were sacrificed, and the rat tissues (brain, heart and liver: $0.3-0.5 \mathrm{~g}$ ) were rapidly removed and homogenized in 10 volumes of $15 \mathrm{mM}$ Krebs buffer. Homogenates were centrifuged at $3000 \mathrm{x}$ for 10 minutes at $4{ }^{\circ} \mathrm{C}$ to give supernatants containing (1.2 mg of protein/ ml; brain), (1.7 mg of protein/ ml; heart) and ( $2.5 \mathrm{mg}$ of protein/ $\mathrm{ml}$; liver) using Coomassie plus protein assay reagent and albumin standard as determined by the Bradford method (Bradford, 1979). During aerobic incubation of the tissue homogenates, MDA released reacts with thiobarbituric acid (TBA) to give a pink colour. The capability of the samples to inhibit MDA formation is used as a measure of their antioxidant activity. The pink colour complex of thiobarbituric acid reacting substance (TBARS) is measured at $532 \mathrm{~nm}$ for the test samples and positive standards (DL- $\alpha$ - tocopherol and BHT) $(200 \mu \mathrm{g} / \mathrm{mL})$, as well as, 2"-O- $\beta$ galactopyranosylvitexin $(100 \mu \mathrm{g} / \mathrm{mL})$. The results were expressed as nanomoles of MDA equivalents per milligram of protein of rat (brain, heart and liver) homogenates. All measurements were done in triplicate. The capability to inhibit MDA formation was calculated using the following equation:

\section{MDA in tissue homogenate with test extracts}

Inhibition effects (\%) =1 MDA in tissue homogenate without test extracts

\section{Statistical Analysis}

All data were expressed as mean \pm SE. Student's t-test [33] was applied for detecting the significance of difference between each sample; $\mathrm{P}<0.05$ was taken as the level of significance.

\section{ACKNOWLEDGEMENT}

The author sincerely thank Prof. Dr. Mohammed Hosny, Professor of Pharmacognosy Department, Faculty of Pharmacy, Al-Azhar University, Cairo, Egypt, for his very kind help throughout this work and structure elucidation of isolated compounds. 


\section{REFERENCES}

Agrawal, P. K.; (1989): “Carbon-13 NMR of Flavonoids”, Elsevier Science: New York, vol 39, p. 466.

Balas L., Vercauteren J., Laguerre M., (1995): Magn. Reson. Chem., 33, 85-94.

Bradford MM. (1976): A rapid and sensitive method for the quantitation of microgram quantities of protein utilizing the principle of protein-dye binding. Anal Biochem.; 72: 248-254.

Chen F. C., Lin Y. M., Chen A. H., (1972): Phytochemistry, 11, 1190-1193.

Chiranjit G.; Hayull Chung; and Rahul, M, (2012): Food and chemical toxicology 302009 2015.

College, J.N.M; (1977): Chinese crude drug dictionary, is ted.shanghai people press, shonghai.

Dong, wnng; Mingyu xia, and Zheng Cui. (2006): Chem..pharm, bull.54 (6) 775-778.

Gongora L, Máñez S, Giner RM, Recio MC, Schinella G, Rios JL. (2003): Inhibition of xanthine oxidase by phenolic conjugates of methylated quinic acid. Planta Med.; 69: 396-401.

Hino T, Kawanish S, Yasui H, Oka S, Sakurai H. (1998): HTHQ (1-O-hexyl-2,3,5 trimethylhydro-quinone), an anti-lipid-peroxidative compound: its chemical and biochemical characterizations. Biochem Biophys Acta.; 1425: 47-60.

Hosny M and Rosazza JP. (2002): Novel oxidations of (+)-catechin by horseradish peroxidase and laccase. J Agric Food Chem.; 50: 5639-5645.

Hosny M, Johnson HA, Ueltschy AK, Rosazza JPN. (2002): Oxidation, reduction, and methylation of carnosic Acid by nocardia. J Nat Prod.; 65: 1266-1269.

Hosny M., Rosazza J. P. N., (1998): J. Nat. Prod., 61, 734-742.

Karl C., Müller G., Pedersen P. A., (1982): Z. Naturforsch, 37c 148-151.

Kim J. P., Kim W. G., Koshino H., Jung J., Yoo I. D., (1996): Phytochemistry, 43, 425-430.

Kim S. H., Hwang K. T., Park J. C., (1992): Kor, J. Pharmacogn., 23, 229-232.

Kitagawa I., Hori K., Sakagami M., Hashiuchi F., Yoshikawa M., Ren J., (1993): Chem. Pharm. Bull., 41, 1350-1357.

Lee D., Kang S. H., Lee S. H., Ro J., Lee K. G., Kinghorn A. D., (2000): Phytochemistry, 53, 405-407.

Lee S. J., Korean Folk (1996): Medicine Monographs Series No. 3. Publishing Center of Seoul National University, Seoul, South Korea.

Mabry T. J., Markham K. R., Thomas M. B., (1970): "The Systematic Identification of Flavonoids", Springer-Verlag: New York, pp 171-324.

Malan E., Pienear D. H., (1987): Phytochemistry, 26, 2049-2051.

Moon Y. H., Rim G. R., (1995): Kor, J. Pharmacogn., 26, 1-7. 
Shahat A. A., Apers S., Miert S. V., Claeys M., Pieters L., Vlietinck A., (2001): Magn. Reson. Chem., 39, 625-629.

Son B. W., Park J. H., Zee O. P., (1989): Arch. Pharm. Res., 12, 219-222.

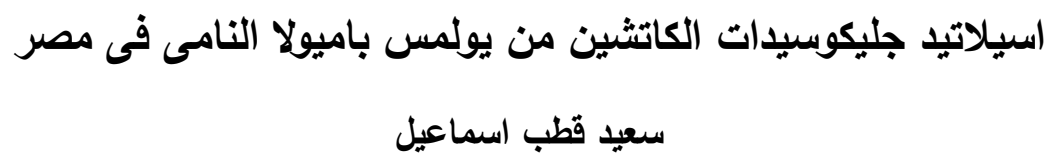

$$
\text { قسم العقاقير - كلية الصيدلة - جامعة الأزهر }
$$

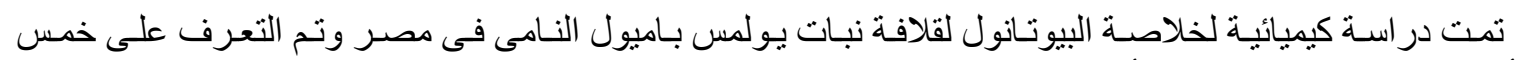

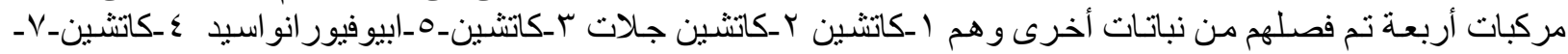

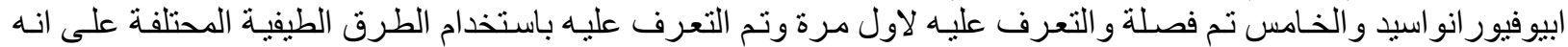

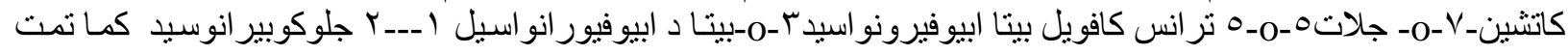


